\title{
Productive Waqf Model as an Alternative for Village-Owned Enterprises Business (BUMDs) Expansion
}

Achmad Fadlil Abidillah

Universitas Airlangga, Indonesia

Achmad.abidillab@gmail.com

\begin{tabular}{|c|c|c|}
\hline Submitted: 2021-09-28 & Revised: 2021-12-01 & Published: 2021-12-31 \\
\hline $\begin{array}{l}\text { C } 2021 \text { by the authors. } \\
\text { of the Creative Commons }\end{array}$ & 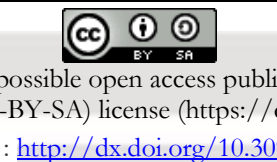 & $\begin{array}{l}\text { terms and conditions } \\
\text { s.org/licenses/by-sa/4.0/) }\end{array}$ \\
\hline
\end{tabular}

This paper aims to create a scientific framework of productive waqf as an alternative financing of business expansions for BUMDes (Badan Usaha Milik. Desa). The design of this research is a literature study on theories related to waqf, productive waqf, and rural development. This study finds literacy facts that waqf is a financial source commonly used by Islamic governments in the past. Then, this paper details a concept of productive waqf as an financing alternative to BUMDes's business expansion, and a systematic model can be formed, which may be a consideration for government policies regarding BUMDes governance, and it is hoped that the application of these findings can provide great benefits for people in rural areas. This finding is expected to be a reference in the framework of scientific thinking in realizing productive waqf as an alternative financing for business expansion from BUMDes and can provide expansive benefits for people in rural areas.

Keywords: waqf, productive waqf, rural development, BUMDes.

\begin{abstract}
Abstrak
Penelitian ini bertujuan untuk membuat suatu kerangka ilmiah konsep wakaf produktif sebagai alternatif pembiayaan ekspansi usaha dari BUMDes. Desain penelitian ini adalah studi kepustakaan mengenai teori-teori yang terkait dengan wakaf, wakaf produktif, serta pembangunan pedesaan. Penelitian ini menemukan fakta literasi bahwa wakaf merupakan sumber finansial yang lazim digunakan oleh pemerintahan Islam di masa silam. Oleh karena itu, penelitian ini kemudian memperinci konsep wakaf produktif sebagai alternatif pembiayaan BUMDes, hingga terbentuk suatu model yang sitematis, bisa menjadi pertimbangan kebijakan pemerintah mengenai tata kelola BUMDes. Sehingga model wakaf produktif dapat menjadi pengembangan terhadap jenis usaha yang dijalankan oleh Badan Usaha Milik Desa, dengan berpatokan kepada tujuan dan prinsip wakaf produktif. Temuan Penelitian ini diharapkan dapat menjadi acuan dalam kerangka berpikir ilmiah dalam mewujudkan wakaf produktif sebagai alternatif pembiayaan ekspansi usaha dari BUMDes dan dapat memberikan manfaat yang besar bagi masyarakat di pedesaan.
\end{abstract}

Kata Kunci: wakaf, wakaf produktif, pembangunan pedesaan, BUMDes.

\section{Introduction}

Incomplete and balanced development is a classic problem for most regions in Indonesia. As a country that has a very wide expanse of territory, development inequality is still the main focus of work for governments that have taken turns leading. Inequality in development between regions, especially between urban and rural areas, is caused by many factors, but the main factor is the lack of funding sources for development due to the lack of independence of a region. Therefore, 
the government is very aggressive in making efforts to increase funding for villages, both those pursued by the central government, regional governments, as well as efforts for independence from the village itself.

The form of efforts to increase village independence in maximizing regional development is the establishment of Village Owned Enterprises (BUMDes). ${ }^{1}$ Since the beginning of the promulgation of the regulation regarding BUMDes until now, there have been 2,465 BUMDes and 311 joint BUMDes that have applied for legal entities, while in general there are around 13,000 BUMDes, both legal entities and those without a legal entity. ${ }^{2}$ However, from several studies conducted on BUMDes that have been operating, there are several problems that cause people to not feel the role of BUMDes in village development, BUMDes are considered to have not contributed to improving the community's economy, there is also a lack of Regional Original Income (PAD) generated by BUMDes, and more important is the lack of funds for business development. ${ }^{3}$ In fact, with business development, the role of BUMDes will be able to be increased.

One of the alternative business development funding that can be maximized is

${ }^{1}$ BUMDes is a business institution owned by the village and managed jointly between the village government and the community, which aims to increase community income in accordance with the potential possessed by the village.

2 Rifqi, "Sebanyak 2.465 Bumdes Sudah Mendaftar di Kemendes PDTT", www.kemendesa.go.id/berita/view/detil/3765/sebanya k-2465-bumdes-sudah-mendaftar-di-kemendes-pdtt, diakses 10 Juni 2021.

3 Maria Rosa Ratna Sri Anggraeni, Peranan Badan Usaha Milik Desa (Bumdes) Pada Kesejahteraan Masyarakat Pedesaan Studi Pada Bumdes Di Gunung Kidul, Yogyakarta', 2017; Edy Yusuf Agunggunanto and others, 'Pengembangan Desa Mandiri Melalui Pengelolaan Badan Usaha Milik Desa (BUMDes)', Jurnal Dinamika Ekonomi \& Bisnis, 13.1 (2016). through waqf. ${ }^{4}$ Waqf is one of the sources of funding known in Islam since the time of the Prophet Muhammad. Waqf is used to build infrastructure such as roads, health facilities, education, and so on. ${ }^{5}$ In addition, the natural purpose of waqf is basically to reduce the income inequality of the community, distribute income between individuals, and ultimately prosper the community through the construction of the required public facilities. ${ }^{67}$ This goal is very much in line with what is expected from the existence of BUMDes.

In Indonesia, many productive waqf practices have been carried out. Qurrata et al, conducted research on productive waqf in Malang. The object of their observation is the Malang Islamic Hospital which is a waqf of the Ma'arif Nahdlatul Ulama Foundation and is managed by the Islamic University of Malang (UNISMA). The productive waqf of this hospital does not only operate in health services, but also has minimarket management in it. As long as this waqf hospital operates, $70 \%$ of the revenue has been allocated for business development, $10 \%$ for nazhir or waqf

4 Abdul H.M. Iman dan Mohammad, Waqf as a framework for entrepreneurship, Humanomics, Vol.33, No.4, h.419-440.

5 Azniza Hartini Azrai Azaimi Ambrose, Mohamed Aslam Gulam Hassan, and Hanira Hanafi, 'A Proposed Model for Financing Public Goods and Mixed Public Goods in Malaysia', International Journal of Islamic and Middle Eastern Finance and Management, 11.3 (2018), 395-415 <https://doi.org/10.1108/IMEFM01-2017-0001>; Syahnaz Sulaiman and others, 'Proposed Models for Unit Trust Waqf and the Parameters for Their Application', ISRA International Journal of Islamic Finance, 11.1 (2019), 62-81 <https://doi.org/10.1108/IJIF-02-2018-0019>;

Muhammad Usman and Asmak Ab Rahman, 'Funding Higher Education through: A Lesson from Pakistan', International Journal of Islamic and Middle Eastern Finance and Management, 14.2 (2021), 409-24 <https://doi.org/10.1108/IMEFM-05-2019-0200>.

6 Mohammad Abdullah, Waqf, Sustainable Development Goals (SDGs) and maqasid al-shariah, International Journal of Social Economics, Vol.45, No.1, 2018, h.158-172.

7 M. Usman dan A.A. Rahman, Funding bigher education through waqf: a lesson from Pakistan, h.410. 
managers, and $20 \%$ for mauquf 'alaih or waqf beneficiaries. This allocation for beneficiaries has a very, very impact on the community because it targets the fields of education, economic empowerment, health facilities, and additional income for the community. ${ }^{8}$

Megawati conducted research on productive waqf at several waqf management institutions in Pekanbaru City. This research applies interview and documentation methods. The objects include the Al-Falah II Mosque, Baitul Mukminin Mosque, Al-Khairat Mosque, Muslim Mosque, and An-Najah Mosque. It turned out that these mosques took advantage of the advantages of waqf land from their waqf to be built into rented houses, boarding houses, and shop houses that were rented out to the public so that they could be productive. The results of this management are then channeled to finance mosque operations and finance the implementation of Madrasah Diniyah Awaliyah (MDA). In general, from the results of this observation, productive waqf run by mosques in Pekanbaru City has provided tangible benefits, although its scope is still very narrow.

Rahman and Widiastuti conducted research on the management of agricultural waqf in Penatarsewu Village, Tanggulangin District, Sidoarjo Regency. This productive waqf in agriculture has been managed by the Muhammadiyah Branch Leadership (PRM) in Penatarsewu Village since 2010. The mudhabarah (collaboration) agreement underlies the collaboration between PRM and sharecroppers. The observation results show that this productive waqf has a good impact on improving the welfare of village farmers.

8 Vika A. Qurrata, et al, The Implementation And Development of Productive Waqf In Indonesia: Case At Malang Islamic Hospital, Humanities \& Social Sciences Reviews, Vol.7, No.4, 2019, h.534.

9 Devi Megawati, Pengelolaan Dan Pengembangan Wakaf Produktif Di Kota Pekanbaru, Hukum Islam, Vol.XIV, No.1, 2014, h.116.
Productive waqf in Penatarsewu Village is able to meet the basic needs of the community such as the fulfillment of food, clothing, and shelter needs. In addition, the productive waqf of Penatarsewu Village also has a good impact on meeting the needs of education and public health. The results from the management of waqf fields are used to finance the schooling of the farmers' children and also to provide health support assistance for the Penatarsewu community. ${ }^{10}$

Philanthropic instruments do have a very important potential role in development, as explained by the UN-SDSN (United Nations - Sustainable Development Solutions Network) in the draft sustainable development framework, that collaboration between the public sector (namely the government) and the private sector (philanthropic institutions), it is hoped that it can spur maximum development in the regions and villages. Many studies on waqf management practices, especially productive waqf, have been carried out by researchers. Most of them concluded that the role of productive waqf management seems to really encourage development in the surrounding environment. Meanwhile, the expansion of productive waqf development that is in contact with small communities at the village level has not been optimized. So that the source of BUMDes funds is always expected from the existing village budget. To improve the business direction of BUMNDes and increase capital by cooperating with productive waqf as an alternative related to business expansion at the BUMDES level. Therefore, this journal will discuss the model of utilizing the concept of productive waqf in the management of Village-Owned Enterprises.

10 Inayah Rahman dan Tika Widiastuti, Model Pengelolaan Wakaf Produktif Sektor Pertanian Untuk Meningkatkan Kesejabteraan Petani (Studi Kasus Pimpinan Ranting Muhammadiyah Penatarsewu Sidoarjo), JESTT, Vol.7, No.3, 2020, h.494. 


\section{Literature Riview Waqf}

Waqf is an Arabic term, and it is explained that linguistically waqf has several meanings, including: 1.) Al-Habs, which means to detain, this term is like when the police detain criminals so that they can no longer commit crimes; 2.) Al-Man'u, which means to prevent, which is like parents who prevent their children from playing with fire; and 3.) As-Sukun, which means to stop or stay still, that is, like a goat that was walking and then stopped and stayed still. ${ }^{11}$

Waqf in terms of, among others: 1.) According to Asy-Shafi'i, waqf is holding property that can be useful with the integrity of its form to be spent on things that are permissible and exist; 2.) According to Hambali, waqf is to withhold useful property from its absolute owner so that it is not released, so that the property remains, then only use it for good things and become worship to Allah Ta'ala; and 3.) According to Abu Hanifah, waqf is holding 'ain an asset with the law remaining as the property of the waqf giver, by giving alms even if only part of the benefits. However, this last opinion received a response from his students who considered that the waqf property had already belonged to Allah Ta'ala. In conclusion, waqf is a charity property whose ownership is retained so that its form is not lost (not traded), and the benefits of the property are used for the benefit of society in general. ${ }^{12}$

The evidence in the Qur'an and AlHadith that underlies the law regarding waqf is as stated in the QS. Ali Imran verse 92:

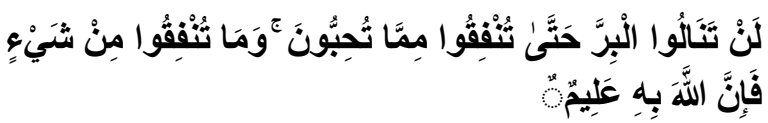

11 Ahmad Sarwat, (2018), Ensiklopedia Fikih Indonesia 7: Muamalat, Jakarta: Gramedia, h.345.

12 Ahmad Sarwat, (2018), h.347. which means: "You will never reach the (perfect) virtue, until you spend part of the wealth you love. And whatever you spend, surely Allah knows it" (Surah Ali Imran: 92). Likewise, the Al-Hadith of the Prophet Muhammad which explains about three human practices (the children and grandchildren of Adam AS) that will continue to flow rewards even though the human has died, namely:

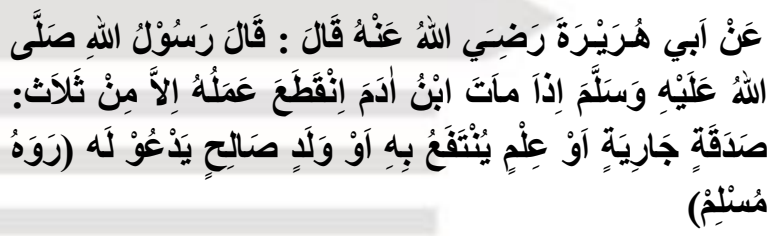

Which means: From Abu Hurairah RA., Rasulullah SAW said: "When Adam's children and grandchildren die, their deeds are cut off except for three things: alms Jariyah, useful knowledge, and pious children who pray for their parents" (HR. Muslim). The majority of scholars agree that the meaning of alms Jariyah in this Hadith is none other than property that is waqf in the way of Allah Ta'ala, which flows continuously as long as the treasure is always beneficial to the public. ${ }^{13}$

Although Islamic scholars differ in their definition of waqf, they agree that waqf requires several provisions related to the pillars and conditions of waqf. The pillars and conditions that must be met include: ${ }^{14}$

- Waqif (people who make waqf). The conditions for waqif are Muslim, aqil and baligh, independent, and not forced or coerced. So, the waqf of people who do not meet the above requirements is invalid.

- Mauquf (waqf property). The requirements for mauquf are: 1) Can be used long term and not disposable; 2) Can be private (absolute) property, group or legal entity; 3) Ownership can

${ }_{13}$ Ahmad Sarwat, (2018), h.350.

14 Ahmad Sarwat, (2018), h.347. 
be transferred; 4) Clear boundaries of ownership; 5) Diverted for the sake of a greater benefit; and 6) Not for sale, not given away, and not inherited.

- Mauquf 'Alaih (beneficiaries of waqf). The point is the purpose of waqf designation, namely anything that is lawful by Islamic law. Should not be directed to something immoral.

- Shighah (pledge of endowment). This pledge consists of ijab by the waqf giver and qabul by the waqf recipient. Waqf pledges can be in the form of a sign or in writing.

- Nazhir (waqf manager). The waqf manager must be a fair and capable person, another purpose is to obey the Shari'a and have creativity in managing assets. Waqf managers in Article 10 of Law Number 41 of 2004 are required: Indonesian citizens, Muslim, mature, trustworthy, capable both physically and spiritually, and not legally disabled.

\section{Productive Waqf}

Morris explained that the concept of productive waqf is an entrepreneurial model with the main source of capital from waqf, be it capital in the form of cash assets or fixed assets such as land and production equipment. The concept of productive waqf is a property mechanism that produces wealth. If it is connected with the conventional concept of entrepreneurship, there will be many similarities. However, the principle of the concept of productive waqf is entrepreneurship that focuses on improving the welfare of society in general, and not for the purpose of personal welfare as conventional entrepreneurship concepts. ${ }^{15}$ Therefore, it can be said that productive waqf

15 Abdul H.M. Iman dan Mohammad, Waqf as a framework for entrepreneurship..., h.420. Achmad Fadlil Abidillah is a very effective wealth distribution instrument. ${ }^{16}$

In a Hadith from Ibn Umar RA, Rasulullah SAW once gave advice to Umar bin Khaththab RA to donate his date garden in Khaibar, as follows:

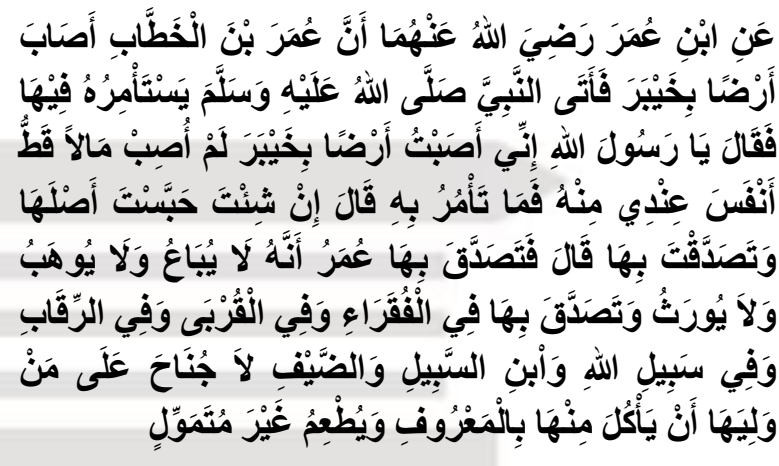

Meaning: "From Ibn Umar RA, that Umar bin Khaththab got a share of land in Khaibar, then he went to the Prophet Muhammad SAW to ask for directions. Umar said: "O Messenger of Allah, I have obtained wealth in the form of very good land, which I have never had before. What would you suggest to me with that wealth?" The Prophet said: "If you want, you can make waqf of it and give charity with it". Then Umar gave his land in charity on the condition that it was not sold, not donated, and not inherited. Umar gave his land to the poor, relatives, to free slaves, sabilillah, ibn sabil, and guests. There is no sin for those who take care of it if they seek or feed from it in a good way and do not hoard it "(HR. Bukhari).

The above hadith explains in great detail how at that time waqf was practiced. If we look at the facts in today's society, waqf is still more dominantly aimed at non-productive sectors, such as waqf for the construction of mosques and other worship facilities, not intending to reduce the benefits of the waqf,

${ }^{16}$ Rahma Jaziyatul Chikmiyah, 'Implementation of Inclusive Finance in Empowering Micro, Small and Medium Enterprises (UMKM) at Micro Waqf Banks', EKONOMIKA SYARLAH: Journal of Economic Studies, 5.1 (2021), <https://doi.org/10.30983/es.v5i1.4294>. 
but it seems that there is still a lot of room for improvement. Waqf can be explored related to waqf, one of which is targeting socio-economic aspects, so that it can have a greater impact on economic development and community welfare, and it has also been described previously that at this time waqf is still very relevant to be used as a source of development funding for the economy. ${ }^{17}$

\section{Rural Development}

The village is an area that has autonomous rights to manage, plan, and carry out its own development to improve the welfare of its people. ${ }^{18}$ Rural development, in Article 5 of Permendagri No. 66 of 2007, is a participatory development model, namely a development management system carried out by deliberation, consensus, and mutual cooperation, which is a way of life for people who have long been entrenched in the territory of Indonesia. Empowerment and participation are two characteristics of rural development. Empowerment means an effort to be able to realize the independence of rural communities, while participatory means active community participation and involvement in the development process. ${ }^{19}$

In the Regulation of the Minister of Villages, Development of Disadvantaged

17 Azrai Azaimi Ambrose, Gulam Hassan, and Hanafi; Nazrul Hazizi Noordin, Siti Nurah Haron, and Salina Kassim, 'Developing a Comprehensive Performance Measurement System for Waqf Institutions', International Journal of Social Economics, 2017; Muhammad Zainul Arifin, 'Pengelolaan Anggaran Pembangunan Desa Di Desa Bungin Tinggi, Kecamatan Sirah Pulau Padang, Kabupaten Ogan Komering Ilir, Sumatera Selatan', Jurnal Thengkyang, Http://Jurnaltengkiang. Ac. Id/Jurnal/Index. Php/JurnalTengkhiang/Issue/View/1/Halaman, $\quad 20.20$ (2018), 1-21.

${ }^{18}$ Muh. Z. Arifin, Pengelolaan Anggaran Pembangunan Desa Di Desa Bungin Tinggi, Kecamatan Sirah Pulau Padang, Kabupaten Ogan Komering Ilir, Sumatera Selatan, Jurnal Thenkyang, Vol.1, No.1, 2018, h.1-21.

19 Peraturan Menteri Dalam Negeri Nomor 66 Tahun 2007 Tentang Perencanaan Pembangunan Desa Pasal 5.
Regions, and Transmigration No. 17 of 2019 Article 3, explains the purpose of village development, among others, is to improve the welfare and quality of life of rural communities, as poverty alleviation through the provision and fulfillment of basic community needs, development of village facilities and infrastructure, development of local economic potential, and sustainable use of natural resources and the rural environment. ${ }^{20}$ All of this seems to be very much in line with what is the purpose of waqf. As stated by Shaikh et al, historically waqf was intended for the construction of public facilities, educational and health institutions as a booster for the quality of life, as well as economic development with long-term impacts. $^{21}$

Rural development, based on Permendes PDTT No. 17 of 2019, implemented with a source of funds, namely village funds. Village funds are funds originating from the state revenue and expenditure budget which are specifically intended for villages and channeled through the regional (district/city) revenue and expenditure budget. This village fund is used to finance the implementation of village governance, implementation of development in the village, financing of village community activities, and also for empowering village communities. $^{22}$

The problem of rural development that is still happening in Indonesia is the focus of the village government's attention on village development which is limited to improving

${ }^{20}$ Peraturan Menteri Desa Pembangunan Daerah Tertinggal dan Transmigrasi Nomor 17 Tahun 2019 Tentang Pedoman Umum Pembangunan dan Pemberdayaan Masyarakat Desa Pasal 3.

${ }^{21}$ Salman A. Shaikh, et al, Application of waqf for social and development finance, ISRA, Vol.9, No.1, 2017, h.5-14.

${ }^{22}$ Peraturan Menteri Desa Pembangunan Daerah Tertinggal dan Transmigrasi Nomor 17 Tahun 2019. 
social welfare and tends to override economic empowerment, such as in programs that are only limited to facilitating the distribution of social assistance. Yet rural development is very complex. ${ }^{23}$ Therefore, it is very necessary to renew programs at the rural level which aim more at empowering the economy of rural communities, which can take advantage of the potential of natural wealth in rural areas in a sustainable manner.

\section{Village Owned Enterprises (BUMDes)}

Village-Owned Enterprises (BUMDes) are business institutions owned by the village and managed jointly between the village government and the community. BUMDes according to Law Number 32 of $2004^{24}$ and also Government Regulation Number 72 of 2005, can be formed and established by villages to increase village income and society in general, in accordance with the needs of the village and the potential possessed by the village. ${ }^{25}$ Meanwhile, in the Regulation of the Minister of Villages, Development of Disadvantaged Regions, and Transmigration Number 4 of 2015, BUMDes is defined in detail as a business entity whose entire capital or part of the capital is owned by the Village, through capital participation originating from village assets and devoted to asset management, services, and business utilization in order to improve the welfare of the village community. ${ }^{26}$

The purpose of the establishment of BUMDes, as explained in the Permendes PDTT Number 4 of 2015 is to improve the

\section{${ }^{23}$ Arifin.}

24 Republik Indonesia, 'Undang-Undang Republik Indonesia Nomor 32 Tahun 2004 Tentang Pemerintahan Daerah', Jakarta (ID): RI, 2004.

25 Peraturan Pemerintah 72 Tahun 2005 Tentang Tentang Desa Bab VII Bagian Kelima Badan Usaha Milik Desa Pasal 78.

${ }^{26}$ Peraturan Menteri Desa Pembangunan Daerah Tertinggal dan Transmigrasi Nomor 4 Tahun 2015 Tentang Pendirian, Pengurusan dan Pengelolaan, dan Pembubaran Badan Usaha Milik Desa Pasal 1. rural economy and rural communities, to optimize and maximize the assets and wealth owned by the village so that it can benefit the welfare of the village, to increase community business through the provision of business development funds. , to build business cooperation between the village government and the private sector, to open and develop market networks, to create jobs, to increase village economic growth and equity, as well as to increase community income and village original income. ${ }^{27}$

The planning and establishment of BUMDes is an initiative of the community and village government, based on cooperative, participatory, and emancipatory principles. These three principles have a very important position in shaping the professionalism of BUMDes performance so that they can target the goals of village welfare. ${ }^{28}$ In addition, Article 4 of the Permendes PDT'T Number 4 of 2015, explains the formation of BUMDes which must consider several things, including village/community initiatives, village potential, village natural resources, human resources, and BUMDes capital. These matters must be agreed upon and discussed through village deliberation forums. ${ }^{29}$

The form of business regulated in Permendes PDTT Number 4 of 2015 is in the form of a Limited Liability Company (PT) and a Micro Finance Institution (LKM). The working principle of this business unit refers to the laws and regulations regarding each form of business, both the laws and regulations regarding PT and the laws that officially regulate MFIs. However, in reality, several BUMDes that have been operating in the regions do not adhere to the complex concept

${ }^{27}$ Peraturan Menteri Desa Pembangunan Daerah Tertinggal dan Transmigrasi Nomor 4 Tahun 2015.

${ }^{28}$ Coristya B. Ramadana, et al, Keberadaan Badan Usaha..., h.1070.

${ }^{29}$ Peraturan Menteri Desa Pembangunan Daerah Tertinggal dan Transmigrasi Nomor 4 Tahun 2015. 
of Limited Liability Companies or Microfinance Institutions in general. Most of them are still in the form of simple farming or animal husbandry, savings and loan businesses between rural communities, as well as small and medium-scale trading businesses. ${ }^{30}$

In the formation of BUMDes, Permendes PDTT Number 4 of 2015 also regulates how BUMDes capital is prepared, namely from the Village Revenue and Expenditure Budget (APB Desa), capital participation from the village, and capital participation from the village community. ${ }^{31}$ More specifically, village capital participation consists of private grants, government assistance, business cooperation, and also assets owned by the village, while community capital participation comes from savings and/or deposits from the community. Although the capital plan has been laid out in detail, the conditions faced by many BUMDes are a lack of capital for business development, which results in the minimal benefit of BUMDes for the community. ${ }^{32}$ Therefore, in this journal, we will discuss productive waqf as an alternative capital for BUMDes.

\section{Research Methodology}

This study applies a qualitative research approach, which uses a literature study method on journals, books, and articles related to the topics taken, namely waqf, productive waqf, rural development, and Village-Owned Enterprises (BUMDes).

Qualitative research is a method that examines meanings, concepts, characters, symptoms, or descriptions of phenomena that are natural and holistic in nature and presented in a narrative manner. The purpose of

\footnotetext{
30 Anggraeni; Agunggunanto and others.

${ }^{31}$ Peraturan Menteri Desa Pembangunan Daerah Tertinggal dan Transmigrasi Nomor 4 Tahun 2015.

32 Coristya Berlian Ramadana, 'Keberadaan Badan Usaha Milik Desa (BUMDES) Sebagai Penguatan Ekonomi Desa', Jurnal Administrasi Publik, 1.6 (2013), 1068-76; Anggraeni; Agunggunanto and others.
}

qualitative research is to solve phenomena and answer questions scientifically and systematically based on quality. ${ }^{33}$ While literature study is a research method that is closely related to theoretical studies sourced from references and scientific literatures, which contain social values or norms that are being studied. $^{34}$

\section{Discussion}

\section{Waqf as a Financial Source}

When we talk about financial sources, the private/private sector will raise stocks and bonds as a source of funding, while the public/government sector tends to prioritize taxes and state debt as a source of funding, but Islamic economics has known waqf since ancient times as a source of funding for its development. ${ }^{35}$ Waqf in the Islamic economy has a role as a provider of public infrastructure such as transportation and state defense, as well as semi-public facilities such as health and education facilities. Some stories about the use of waqf as funding for state infrastructure are when the Prophet Muhammad used the property left by Mukhayriq, a Jew who died in the war, as waqf to finance defense, and the well-known waqf of Uthman bin Affan RA as an example of waqf funding for a clean water infrastructure. ${ }^{36}$

In the era of the Islamic caliphate after the leadership of Khulafa ar-Rasyidin, the role of waqf became increasingly important as part of the state budget. During the Umayyad Caliphate, the Diwan Al-Ahbas institution was formed as a waqf manager, and at that time the role of waqf was widely used as a source of funding for the construction of educational

33 Umar Sidiq dan M.M. Choiri, (2019), Metode Penelitian Kualitatif di Bidang Pendidikan, Natakarya: Ponorogo, h.4.

${ }^{34}$ Sugiyono, (2012), Metode Penelitian Kuantitatif Kualitatif dan R\&D, Bandung: Alfabeta, h.291.

${ }^{35}$ Azrai Azaimi Ambrose, Gulam Hassan, and Hanafi; Usman and Ab Rahman.

36 Azrai Azaimi Ambrose, Gulam Hassan, and Hanafi. 
facilities, including being allocated for library construction, funding the salaries of teachers, and even being used to provide scholarships to students. ${ }^{37}$ When the sultan Salahuddin continued the caliphate of the Abbasids, waqf was made part of the state's fiscal reforms. The Sultan donated many public facilities such as educational institutions, public baths, orchards, and shopping facilities. Like the caliph AlMa'mun who once led, Sultan Salahuddin also made a kind of portfolio for waqf for the sake of the sustainability of a certain educational institution.

The waqf system became a legacy for the Ottoman Empire, and reached its peak during these times. It is even stated that the income from waqf at that time was equivalent to one-third of the income of the sultanate at the end of the eighteenth century. Its uses have included funding schools, assisting retired sailors, building commuter ships, funding city defenses, managing water supplies, and also for expanding employment opportunities. 38 Shaham mentioned that Christians and Jews during the reign of the Ottomans formed financial institutions that were identical to the waqf system for the procurement of assets such as warehouses, shops, houses, apartments, and others. ${ }^{39}$

Some of the descriptions above explain how waqf plays a very crucial role as a source of funding for the Islamic economy and waqf is still very relevant if used as a source of development funding. Waqf in the past was part of the state's fiscal instrument that could be used as a means of redistribution of income from those who have excess assets to those in need through the construction of public facilities that have a role in community

37 Azrai Azaimi Ambrose, Gulam Hassan, and Hanafi. ${ }^{38}$ Timur Kuran, The Provision Of Public Goods Under Islamic Law: Origins, Impact, And Limitations Of The Waqf System, Law\& Society Review, Vol.35, No.4, 2001, h.841-898.

${ }^{39}$ Azniza H. Ambrose, et al, A Proposed..., h.401. Achmad Fadlil Abidillah empowerment, so that it also has an impact on increasing the welfare of the community. ${ }^{40}$

\section{Productive Waqf and BUMDes Business Expansion}

As previously explained, the main objectives of rural development are improving welfare and quality of life, reducing poverty through meeting the basic needs of the community, developing village facilities and infrastructure, and empowering and developing the potential of the local economy. ${ }^{41}$ What is the goal of rural development is very much in line with the natural purpose of the existence of waqf in ancient times, as explained by Abdullah and Sulaiman et al, that the benefits of waqf target several sectors such as health services, scientific development and educational facilities, infrastructure development, and even unemployment alleviation. ${ }^{42}{ }^{43}$

According to Abdullah, there is a lot of literature that has proven the close relationship between waqf and development. However, the problem that arises today is how the framework of development through waqf is appropriate in the context of global life. Because currently the existing literature has quite a lot to describe the potential of waqf and the success of waqf in the past, but there is still little that describes practically how the realization of the potential of waqf is. Therefore, there is a need for a tactical step to utilize productive waqf that can maximize rural development, so that the ultimate goal of rural development can be achieved immediately. ${ }^{44}$

40 Noordin, Haron, and Kassim; Azrai Azaimi Ambrose, Gulam Hassan, and Hanafi.

${ }^{41}$ Peraturan Menteri Desa Pembangunan Daerah Tertinggal dan Transmigrasi Nomor 11 Tahun 2019 Bab II.

42 Mohammad Abdullah, Waqf, Sustainable Development Goals.., h.158.

${ }^{43}$ Syahnaz Sulaiman, et al, Proposed models.., h.64.

44 Mohammad Abdullah, Waqf, Sustainable Development Goals.., h.160. 
One of the rural development instruments whose position is very strategic is BUMDes (Village Owned Enterprises). BUMDes ownership is the right of the village community at large, which must move to improve the welfare of the village community. However, the obstacles faced by BUMDes are the lack of capital for their business development, and productive waqf is able to become an alternative funding, due to the congruence of objectives between BUMDes and productive waqf. ${ }^{454647}$ As explained by Abdullah in his journal, collaboration between institutions is an important key in waqf management. If the context is rural in Indonesia, then there needs to be cooperation and collaboration between Village-Owned Enterprises, village governments, regional waqf institutions, and nazhir at the rural level. ${ }^{48}$

\section{BUMDes Management Model with Productive Waqf Funding}

BUMDes in this concept acts as a nazhir in the form of a business entity. Productive waqf businesses that can be practiced in rural areas, for example, are agricultural businesses, plantation businesses, fishing businesses, and other simple businesses such as trading businesses or rental service businesses. BUMDes obtain business funds from the APBD, village capital, and community capital, in addition to obtaining waqf funds to be productive. However, even so, business administration must still be carried out separately, so that there is transparency in activities between BUMDes businesses whose capital comes from waqf funds and whose capital does not come from waqf funds. This

${ }^{45}$ Coristya B. Ramadana, et al, Keberadaan Badan Usaha..., h.1074.

${ }^{46}$ Maria R.R.S. Anggraeni, Peranan Badan Usaha Milik Desa (Bumdes)..., h.161.

${ }^{47}$ Edy Y. Agunggunanto, et al, Pengembangan Desa Mandiri Melalui..., h.79.

48 Mohammad Abdullah, Waqf, Sustainable Development Goals.., h.164. administration is important, considering that the business results from waqf which must be distributed transparently are allocated for three things, namely for business business development, to be distributed to beneficiaries or mauquf 'alaih, and for the salaries of waqf business unit managers or nazhir. ${ }^{49}$

The regional waqf institution, the Indonesian Waqf Agency (BWI), acts as a regulator of rural waqf management. Regional representative BWI, in line with its main function, acts as a builder and supervisory institution for waqf management in the village. ${ }^{50}$ In addition, BWI also has a special task to carry out job training for prospective nazhir, so that the professionalism of nazhir's work can be maximized. In addition to BWI, there is the Ministry of Villages, Development of Disadvantaged Regions and Transmigration (Kemendes PDTT) which also acts as a regulator, especially for BUMDes itself, because the main foundation for BUMDes governance must still follow the regulations that have been prepared by the Kemendes PDTT, both related to transparency and business progress.

Even though the waqf management institution is a non-profit institution, in practice this institution must demonstrate management professionalism and financial accountability so that it can be seen as a trusted institution. ${ }^{515253}$ In this case, BUMDes waqf must also carry the same spirit as a professional social business management institution. Through the professionalism of the institution, the development of waqf funds will also

49 Vika A. Qurrata, et al, The Implementation And Development..., h.534.

${ }^{50}$ Peraturan Badan Wakaf Indonesia Nomor 1 Tahun 2007 Tentang Organisasi dan Tata Kerja Badan Wakaf Indonesia Bab IV Pasal 8.

${ }^{51}$ Salman A. Shaikh, et al, Application of..., h.11.

${ }^{52}$ Syahnaz Sulaiman, et al, Proposed models.., h.66.

53 M. Usman dan A.A. Rahman, Funding bigher education..., h.413. 
certainly increase and will also have an impact on the creation of productive waqf schemes that are more complex and have a high social impact. In addition, waqf BUMDes must also be able to provide employment opportunities for rural communities, so that they can be empowered.

Waqf assets can be collected from the wider community. These assets are not limited to money only, but can also be in the form of other assets such as land, buildings, or production equipment related to the business form of BUMDes. These assets are then accountably handed over to BUMDes as nazhir, and then used productively so as to produce economic outputs that can generate benefits in the form of profits. This turnover of waqf assets is described by Iman and Muhammad $^{54}$ in their journal, which is used for business strengthening and business expansion, so that they can continue to increase the business potential of BUMDes. In general, the BUMDes operational framework that implements productive waqf is described as follows:

Figure 1.1

BUMDes Model with Productive Waqf Funding Alternatives.

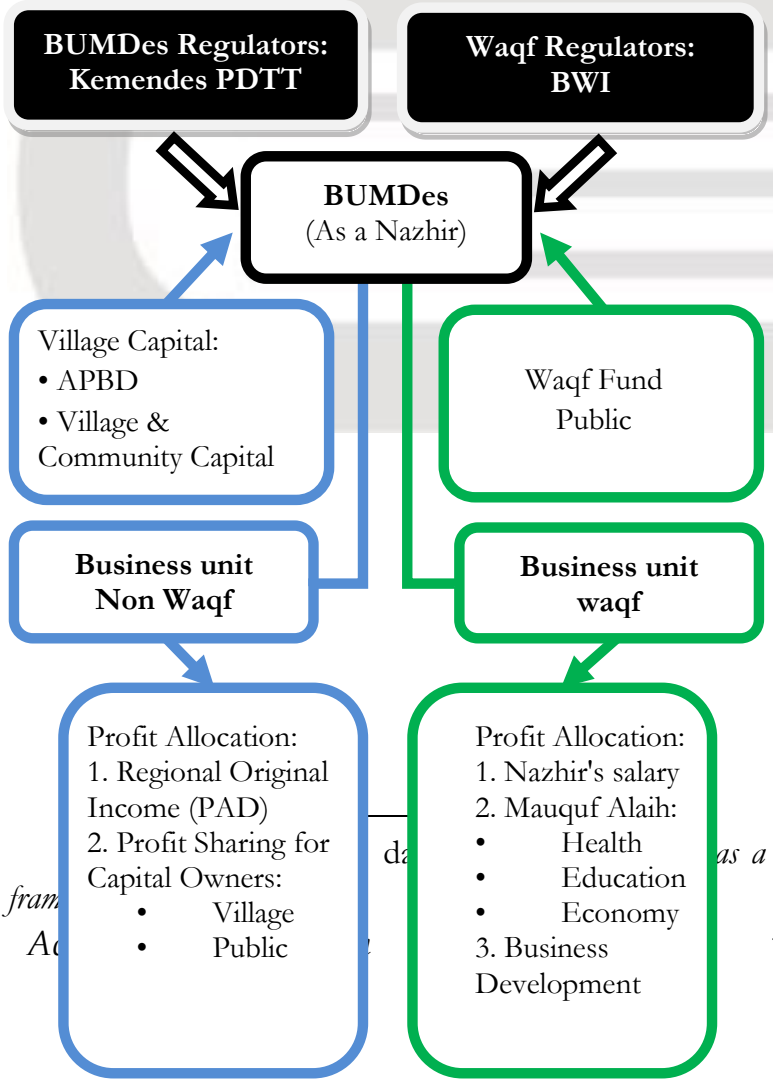

Description:

$\Longrightarrow$ Setting, Training and Supervision

Inflow and outflow of funds.

\section{Source: Researcher}

\section{Conclusion}

Waqf has been since the time of the Prophet Muhammad as a source of finance and funding for the development of the country. The natural purpose of waqf is very much in line with the ideals of development in Indonesia, especially rural development, namely improving the quality of life, eradicating poverty, and increasing people's welfare. Waqf, when used productively, will not only target the social aspect in society, but will also target the economic aspect..$^{55}$ After the era of prophethood and the leadership of the companions of the Prophet, waqf became increasingly central to the state's fiscal position. Until today, waqf still seems relevant to be used as an instrument of development funding. Therefore, a model for village business institutions that integrates productive waqf as a source of funding has been developed. Through collaboration between institutions, productive waqf in rural areas is expected to be able to drive village development to achieve development goals both in the social and economic fields.

\section{Bibliography}

Agunggunanto, Edy Yusuf, Fitrie Arianti, Edi Wibowo Kushartono, and Darwanto Darwanto, 'Pengembangan Desa Mandiri Melalui Pengelolaan Badan Usaha Milik Desa (BUMDes)', Jurnal Dinamika Ekonomi \& Bisnis, 13.1 (2016)

Anggraeni, Maria Rosa Ratna Sri, 'Peranan Badan Usaha Milik Desa (Bumdes) Pada Kesejahteraan Masyarakat Pedesaan Studi Pada Bumdes Di Gunung Kidul, Yogyakarta', 2017

Arifin, Muhammad Zainul, 'Pengelolaan

55 Abdul H.M. Iman dan Mohammad, Waqf as a framework..., h.421. 
Anggaran Pembangunan Desa Di Desa Bungin Tinggi, Kecamatan Sirah Pulau Padang, Kabupaten Ogan Komering Ilir, Sumatera Selatan', Jurnal Thengkyang, Http:/ / Jurnaltengkiang. Ac.

Id/Jurnal/Index.

Php/JurnalTengkhiang/Issue/View/1/Hala man, 20.20 (2018), 1-21

Azrai Azaimi Ambrose, Azniza Hartini, Mohamed Aslam Gulam Hassan, and Hanira Hanafi, 'A Proposed Model for Financing Public Goods and Mixed Public Goods in Malaysia', International Journal of Islamic and Middle Eastern Finance and Management, 11.3 (2018), 395-415 $<$ https://doi.org/10.1108/IMEFM-012017-0001>

Chikmiyah, Rahma Jaziyatul, 'Implementation of Inclusive Finance in Empowering Micro, Small and Medium Enterprises (UMKM) at Micro Waqf Banks', EKONOMIKA SYARIAH: Journal of Economic Studies, 5.1 (2021), 82 <https://doi.org/10.30983/es.v5i1.4294 $>$

Hansen, Gary E, Agricultural and Rural Development in Indonesia (Routledge, 2019)

Indonesia, Republik, 'Undang-Undang Republik Indonesia Nomor 32 Tahun 2004 Tentang Pemerintahan Daerah', Jakarta (ID): RI, 2004

Neumeier, Stefan, Why Do Social Innovations in Rural Development Matter and Should They Be Considered More Seriously in Rural Development Research?-Proposal for a Stronger Focus on Social Innovations in Rural Development Research', Sociologia Ruralis, 52.1 (2012), 48-69

Noordin, Nazrul Hazizi, Siti Nurah Haron, and Salina Kassim, 'Developing a Comprehensive Performance Measurement System for Waqf Institutions', International Journal of Social Economics, 2017

Ramadana, Coristya Berlian, 'Keberadaan Badan Usaha Milik Desa (BUMDES) Sebagai Penguatan Ekonomi Desa', Jurnal Administrasi Publike, 1.6 (2013), 1068-76

Sulaiman, Syahnaz, Aznan Hasan, Azman Mohd Noor, Muhd Issyam Ismail, and
Nazrul Hazizi Noordin, 'Proposed Models for Unit Trust Waqf and the Parameters for Their Application', ISRA International Journal of Islamic Finance, 11.1 (2019), 62-81 $<$ https://doi.org/10.1108/IJIF-02-20180019>

Usman, Muhammad, and Asmak Ab Rahman, 'Funding Higher Education through: A Lesson from Pakistan', International Journal of Islamic and Middle Eastern Finance and Management, 14.2 (2021), 409-24 $<$ https://doi.org/10.1108/IMEFM-052019-0200>

Sarwat, Ahmad, (2018), Ensiklopedia Fikih Indonesia 7: Muamalat, Jakarta: Gramedia.

\section{Jurnal Ilmiah}

Abdullah, Mohammad, Waqf, Sustainable Development Goals (SDGs) and maqasid al-shariah, International Journal of Social Economics, Vol.45, No.1, 2018, h.158-172.

Agunggunanto, Edy Y., et al, Pengembangan Desa Mandiri Melalui Pengelolaan Badan Usaha Milik Desa (Bumdes), Jurnal Dinamika Ekonomi \& Bisnis, Vol.13, No.1, 2016, h.67-81.

Ambrose, Azniza H., et al, A Proposed Model For Waqf Financing Public Goods And Mixed Public Goods In Malaysia, International Journal of Islamic and Middle Eastern Finance and Management, Vol.11, No.3, 2018, h.395-415.

Anggraeni, Maria R.R.S., Peranan Badan Usaha Milik Desa (Bumdes) Pada Kesejahteraan Masyarakat Pedesaan Studi Pada Bumdes Di Gunung Kidul, Yogyakarta, Modus, Vol.28, No.2, 2016, h.155-167.

Arifin, Muhammad Z., Pengelolaan Anggaran Pembangunan Desa Di Desa Bungin Tinggi, Kecamatan Sirah Pulau Padang, Kabupaten Ogan Komering Ilir, Sumatera Selatan, Jurnal Thenkyang, Vol.1, No.1, 2018, h.1-21. 
Iman, Abdul H.M. dan Mohammad T.S.H.M., Waqf as a framework for entrepreneurship, Humanomics, Vol.33, No.4, h.419-440.

Kuran, Timur, The Provision Of Public Goods Under Islamic Law: Origins, Impact, And Limitations Of The Waqf System, Law\& Society Review, Vol.35, No.4, 2001, h.841898.

Megawati, Devi, Pengelolaan Dan Pengembangan Wakaf Produktif Di Kota Pekanbaru, Hukum Islam, Vol.XIV, No.1, 2014, h.116.

Neumeier, Stefan, Why do Social Innovations in Rural Development Matter and Should They be Considered More Seriously in Rural Development Research? - Proposal for a Stronger Focus on Social Innovations in Rural Development Research. Sociologia Ruralis, Vol.52, No.1, 2012, h.48-69.

Noordin, Nazrul H., et al, Developing a Comprehensive Performance Measurement System for Waqf Institutions, International Journal of Social Economics, Vol.44, No.7, 2017, h.921-936.

Qurrata, Vika A., et al, The Implementation And Development Of Productive Waqf In Indonesia: Case At Malang Islamic Hospital, Humanities \& Social Sciences Reviews, Vol.7, No.4, 2019, h.534.

Rahman, Inayah dan Tika Widiastuti, Model Pengelolaan Wakaf Produktif Sektor Pertanian Untuk Meningkatkan Kesejahteraan Petani (Studi Kasus Pimpinan Ranting Muhammadiyah Penatarsewu Sidoarjo), JESTT, Vol.7, No.3, 2020, h.494.

Ramadana, Coristya B., et al, Keberadaan Badan Usaha Milik Desa (Bumdes) Sebagai Penguatan Ekonomi Desa (Studi di Desa Landungsari, Kecamatan Dau, Kabupaten
Malang), Jurnal Administrasi Publik, Vol.1, No.6, 2013, h.1068-1076.

Shaikh, Salman A., et al, Application of waqf for social and development finance, ISRA, Vol.9, No.1, 2017, h.5-14.

Sulaiman, Syahnaz, et al, Proposed models for unit trust waqf and the parameters for their application, ISRA, Vo.11, No.1, 2019, h.62-81.

Usman, M. dan A.A. Rahman, Funding higher education through waqf: a lesson from Pakistan, International Journal of Islamic and Middle Eastern Finance and Management, Vol.14, No.2, 2020, h.409-424.

\section{Peraturan}

Peraturan Badan Wakaf Indonesia Nomor 1 Tahun 2007 Tentang Organisasi dan Tata Kerja Badan Wakaf Indonesia Bab IV Pasal 8.

Peraturan Menteri Dalam Negeri Nomor 66 Tahun 2007 Tentang Perencanaan Pembangunan Desa Pasal 5.

Peraturan Menteri Desa Pembangunan Daerah Tertinggal dan Transmigrasi Nomor 17 Tahun 2019 Tentang Pedoman Umum Pembangunan dan Pemberdayaan Masyarakat Desa.

Peraturan Menteri Desa Pembangunan Daerah Tertinggal dan Transmigrasi Nomor 4 Tahun 2015 Tentang Pendirian, Pengurusan dan Pengelolaan, dan Pembubaran Badan Usaha Milik Desa.

Peraturan Menteri Desa Pembangunan Daerah Tertinggal dan Transmigrasi Nomor 11 Tahun 2019 Bab II.

Peraturan Pemerintah 72 Tahun 2005 Tentang Tentang Desa Bab VII Bagian Kelima Badan Usaha Milik Desa Pasal 78.

Undang-Undang 32 Tahun 2004 Tentang Pemerintahan Desa Pasal 157.

\section{Referensi Online dan Wawancara}


Rifqi, "Sebanyak 2.465 Bumdes Sudah Mendaftar di Kemendes PDT'T", www.kemendesa.go.id/berita/view Ldetil/3765/sebanyak-2465bumdes-sudah-mendaftar-dikemendes-pdtt, diakses pada 10 Juni 2021.
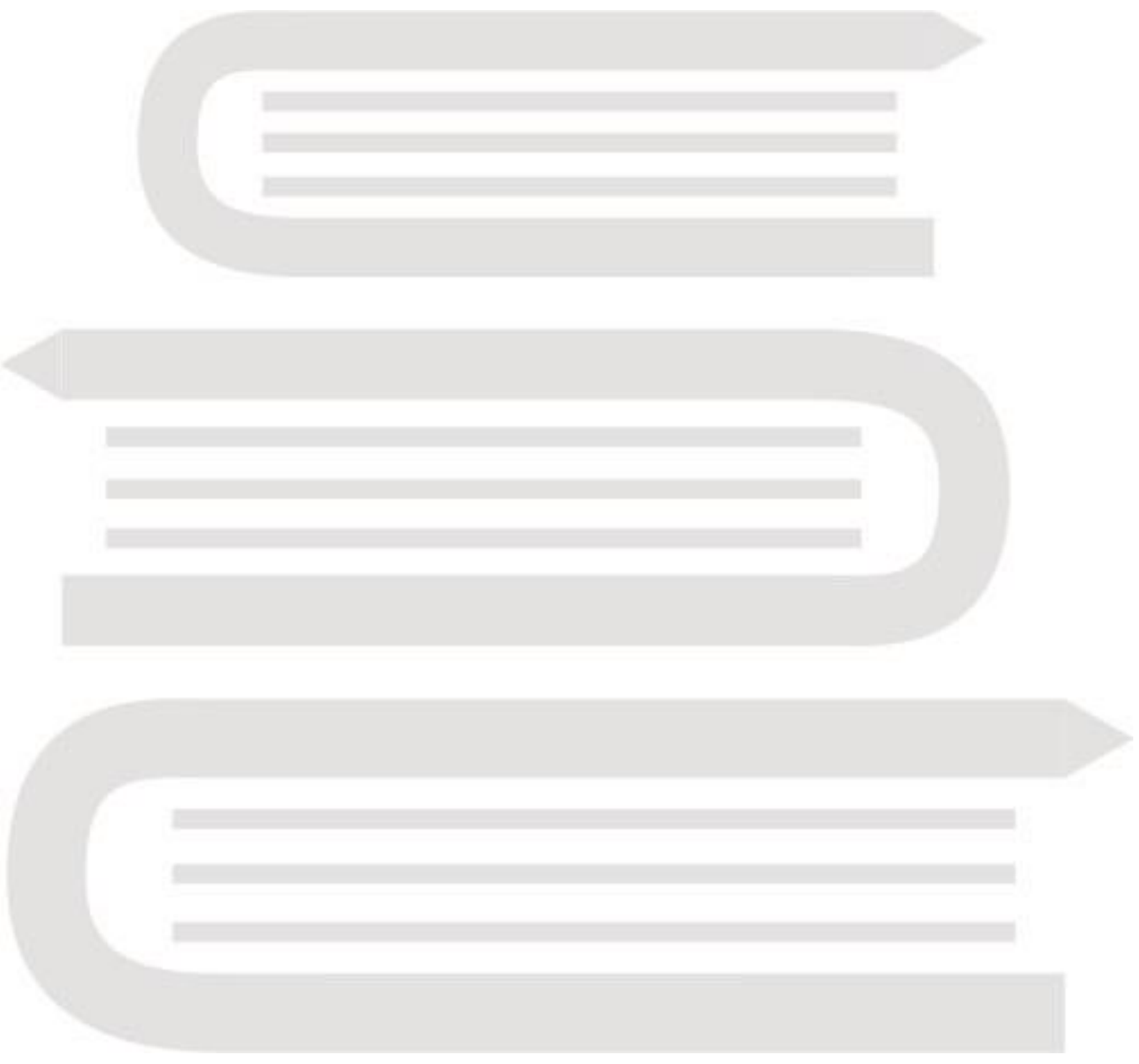